\title{
Characterization of a novel human catechol- $O$-methyl- transferase mutant with triplet point mutations
}

\author{
HYOUNG-WOO BAI, PAN WANG and BAO TING ZHU
}

\author{
Department of Pharmacology, Toxicology and Therapeutics, School of Medicine, \\ University of Kansas Medical Center, Kansas City, KS 66160, USA
}

Received June 19, 2008; Accepted August 11, 2008

DOI: 10.3892/ijmm_00000084

\begin{abstract}
Human catechol- $O$-methyltransferase (COMT, EC 2.1.1.6) catalyzes the transfer of the methyl group to a variety of endogenous and exogenous catechol substrates using $S$ adenosyl- $L$-methionine as the methyl donor. This enzymatic $O$-methylation plays an important role in the inactivation of biologically-active and toxic catechols. A number of studies in recent years have sought to characterize the polymorphism of human COMT, and also to determine the catalytic activity of polymorphic enzymes. We report here the identification of a new haplotype of the human COMT gene with triplet point mutations, which encodes the D51G/S60F/K162R mutant of the soluble COMT and the D101G/S110F/K212R mutant of the membrane-bound COMT. Kinetic analysis showed that these new COMT variants had essentially the same kinetic characteristics and catalytic activity as the wild-type COMTs for the $O$-methylation of 2 -hydroxyestradiol and 4hydroxyestradiol in vitro, but they have a significantly reduced thermostability at $37^{\circ} \mathrm{C}$. In addition, the mutant enzymes have different binding affinities for $S$-adenosyl- $L$-methionine compared with the wild-type COMTs. In agreement with our biochemical observations, molecular modeling studies also showed that the variant human COMT proteins shared nearly the same overall structures as the wild-type proteins. The binding energy values of the mutant COMTs in complex with catechol estrogen substrates were similar to those of the wildtype COMTs bound with the same substrates.
\end{abstract}

Correspondence to: Dr Bao Ting Zhu, Department of Pharmacology, Toxicology and Therapeutics, University of Kansas Medical Center, MS-1018, room KLSIC-4061, 2146 W, 39th Ave, Kansas City, KS 66160, USA

E-mail: btzhu@kumc.edu

Abbreviations: COMT, catechol- $O$-methyltransferase; $\mathrm{E}_{2}, 178-$ estradiol; 2-OH-E $\mathrm{E}_{2}$ and 4-OH-E 2 , 2- and 4-hydroxyestradiol, respectively; AdoMet, $S$-adenosyl- $L$-methionine; AdoHcy, $S$ adenosyl- $L$-homocysteine

Key words: catechol-O-methyltransferase, catechols

\section{Introduction}

Human catechol- $O$-methyltransferase (COMT; EC 2.1.1.6) catalyzes the transfer of the methyl group to a wide variety of endogenous and exogenous catechol substrates by using $S$ adenosyl- $L$-methionine (AdoMet) as the methyl donor (1-8). In the central nervous system, COMT metabolically deactivates catecholamine neurotransmitters (dopamine and norepinephrine) through $O$-methylation. The human COMT exists in two different forms, the soluble form (S-COMT) and the membrane-bound form (MB-COMT), which are encoded by a single gene $(8,9)$. A decrease in the methylation of catecholamine neurotransmitters due to the presence of a thermolabile S-COMT variant (V108M) has been associated with an increased risk for Parkinson's disease $(3,9)$, the development of a chronic pain condition (10-12), and also a number of mental disorders (12-21). In addition to catecholamine neurotransmitters, the endogenous catechol estrogens, such as 2- and 4-hydroxyestradiol (2-OH- $\mathrm{E}_{2}$ and 4-OH-E 2 , which are major oxidative metabolites of $173-$ estradiol $\left(\mathrm{E}_{2}\right)$ formed by cytochrome $\mathrm{P} 450$ isoforms in humans $(22,23)$, are also rapidly $O$-methylated by COMT, in a manner analogous to the $O$-methylation of catecholamines (21). A number of studies have demonstrated that metabolic $O$-methylation provides effective inactivation/detoxification of the procarcinogenic catechol estrogen intermediates. The major $O$-methylation product of 2-OH-E 2 (2-methoxyestradiol) has strong apoptotic, antiangiogenic, and anticancer actions [reviewed in refs. $(3,24)$ ]. Hence, metabolic $O$-methylation of catechol estrogens may not only inactivate the catechol estrogen intermediates, but may also simultaneously produce 2-methoxyestradiol that has significant anticancer activity (24). These two concurrent processes are thought to be beneficial for reducing the risk of estrogen-induced cancers (24). In line with this suggestion, many epidemiological studies have shown that women, homozygous with a thermolabile variant (V108M) of S-COMT, have an increased risk of estrogen-associated cancers (25-32), thus providing support for this interesting hypothesis.

Given the potentially important biological consequences associated with a reduced COMT catalytic activity in vivo, a number of studies in recent years have sought to investigate the polymorphism of the human COMT gene, as well as its effect on the catalytic activity of the enzyme (33-37). At present, a total of 14 polymorphisms (summarized in Table I) 
Table I. The COMT polymorphisms listed in the NCBI SNP database (http://www.ncbi.nlm.nih.gov/SNP).

\begin{tabular}{|c|c|c|c|}
\hline \multirow{2}{*}{$\begin{array}{l}\text { Amino acid positions } \\
\text { (S/MB) }\end{array}$} & \multicolumn{2}{|c|}{ Amino acid residue } & \multirow{2}{*}{$\begin{array}{l}\text { Effect on the catalytic activity } \\
\text { of the enzyme per se }\end{array}$} \\
\hline & Wild-type & Mutant & \\
\hline$-/ 9$ & $\mathrm{~L}$ & $\mathrm{~F}$ & Unknown (unpublished) \\
\hline$-/ 34$ & $\mathrm{C}$ & $\mathrm{S}$ & Unknown (unpublished) \\
\hline $12 / 62$ & $\mathrm{H}$ & $\mathrm{H}^{\mathrm{a}}$ & No change (32) \\
\hline $22 / 72$ & A & $\mathrm{S}$ & $\begin{array}{l}\text { Lower catalytic activity and } \\
\text { reduced thermostability (33) }\end{array}$ \\
\hline $23 / 73$ & Q & $\mathrm{Q}^{\mathrm{a}}$ & No change \\
\hline $42 / 92$ & $\mathrm{~V}$ & M & Unknown (unpublished) \\
\hline $52 / 102$ & A & $\mathrm{T}$ & Reduced thermostability (33) \\
\hline $62 / 112$ & $\mathrm{~L}$ & $\mathrm{~L}^{\mathrm{a}}$ & No change \\
\hline $84 / 134$ & A & $\mathrm{A}^{\mathrm{a}}$ & No change \\
\hline $86 / 136$ & $\mathrm{~L}$ & $\mathrm{~L}^{\mathrm{a}}$ & No change (32) \\
\hline $96 / 146$ & A & $\mathrm{V}$ & Unknown (unpublished) \\
\hline $108 / 158$ & $\mathrm{~V}$ & $\mathrm{M}$ & Reduced thermostability $(17,29-32)$ \\
\hline 149/199 & $\mathrm{P}$ & $\mathrm{L}$ & Unknown (unpublished) \\
\hline $153 / 203$ & $\mathrm{~L}$ & $\mathrm{~L}^{\mathrm{a}}$ & No change \\
\hline
\end{tabular}

aThese nucleic acid mutations will not alter the amino acids that are encoded by the altered codons.

are listed in the NCBI SNP database for the coding regions (exons) of the human COMT gene, and each of them are single point mutations. Among them, only three of the COMT mutants have been studied for their enzymatic activity and functional differences with the wild-type COMT. The V108M mutant of human S-COMT was found to retain nearly the same catalytic ability for the $O$-methylation of catechol estrogen substrates as the wild-type COMT, but it had a reduced thermostability (32-36). In comparison, the A22S mutant of the human S-COMT had a lower catalytic activity and also reduced thermostability (37).

In the present study, we identified a new haplotype of the human COMT gene. In addition, we have selectively expressed the wild-type and mutant human S- and MBCOMTs in Escherichia coli (E. coli) for comparing their biochemical characteristics for the $O$-methylation of endogenous catechol estrogens. Using S-COMT as an example, we additionally conducted computational molecular modeling studies to compare the structural and catalytic differences between the wild-type and variant enzymes.

\section{Materials and methods}

Chemicals. 2-OH- $\mathrm{E}_{2}, 4-\mathrm{OH}-\mathrm{E}_{2}$, isopropylthio- $\mathrm{B}-\mathrm{D}$-galactoside (IPTG), 1,4-dithiothreitol (DTT) and phenylmethylsulfonyl fluoride (PMSF), $S$-adenosyl- $L$-methionine (AdoMet) were purchased from Sigma-Aldrich (St. Louis, MO). (Methyl- ${ }^{3} \mathrm{H}$ ) AdoMet (specific activity, 11.2-13.5 Ci/mmol) was obtained from Perkin Elmer (Waltham, MA). All solvents used in this study were of HPLC grade or higher and were obtained from Fisher Scientific Co. (Springfield, NJ).

Cloning of human S-COMT and MB-COMT cDNAs. The human liver cDNA library, obtained from Stratagene (La Jolla, CA), was generated from pooled normal liver tissues from two females, and was used as a template for cloning the human $S$-COMT and $M B-C O M T$ cDNAs. For PCR, the 5 complementary forward primers (5'-CAA CAT ATG CCG GAG GCC CCG-3' and 5'-GCA TAT GCC GGA GGC CCC GCC TC-3') were used for S-COMT and MB-COMT respectively, along with a common $3^{\prime}$ reverse primer $\left(5^{\prime}\right.$ CAG GAT CCT CAG GGC CCT GCT-3'). These primers were specifically designed to append the sequence that contains a 5' NdeI restriction site and a 3' BamHI restriction site (Fig. 1, lower panel). The resulting 655-bp fragment for $S$-COMT and the 815-bp fragment for $M B$-COMT amplified by PCR were eluted using a gel extract kit (Qiagen, Valenica, CA), and they were then ligated to the pGEM T vector (Promega, Madison, WI) using T4 ligase (Invitrogen, Carlsbad, CA). The products of the ligation reactions were transformed into the chemically competent E. coli TOP-10F' cells (Invitrogen, Carlsbad, CA), and the transformed bacteria were then selected with ampicillin $(50 \mu \mathrm{g} / \mathrm{ml})$ on LB agar plates. The plasmids were purified using a Miniprep purification kit (Qiagen, Valencia, CA). The entire S-COMT and $M B-C O M T$ cDNA sequences were determined for verification. Note that three different types of DNA polymerase, i.e., ExTaqDNA polymerase (Takara, Madison, WI), PfuTurbo DNA polymerase (Staratagene, La Jolla, CA), and HotStarTaq DNA polymerase (Qiagen, Valencia, CA), all of which have high fidelity and proof-reading capability, were used for the PCR for cloning the human S-COMT and $M B$-COMT cDNAs. The resulting cDNA products from three different DNA polymerases were sequenced and the sequences matched each other. In addition, the sequences of the overlapping regions of the $S-C O M T$ and $M B-C O M T$ cDNAs also matched each other.

The plasmids were then restriction-digested with $N d e I$ and BamHI and ligated into NdeI and BamHI-digested pET12a vector (Novagen, Madison, WI). The recombinant 


\section{COMT gene}
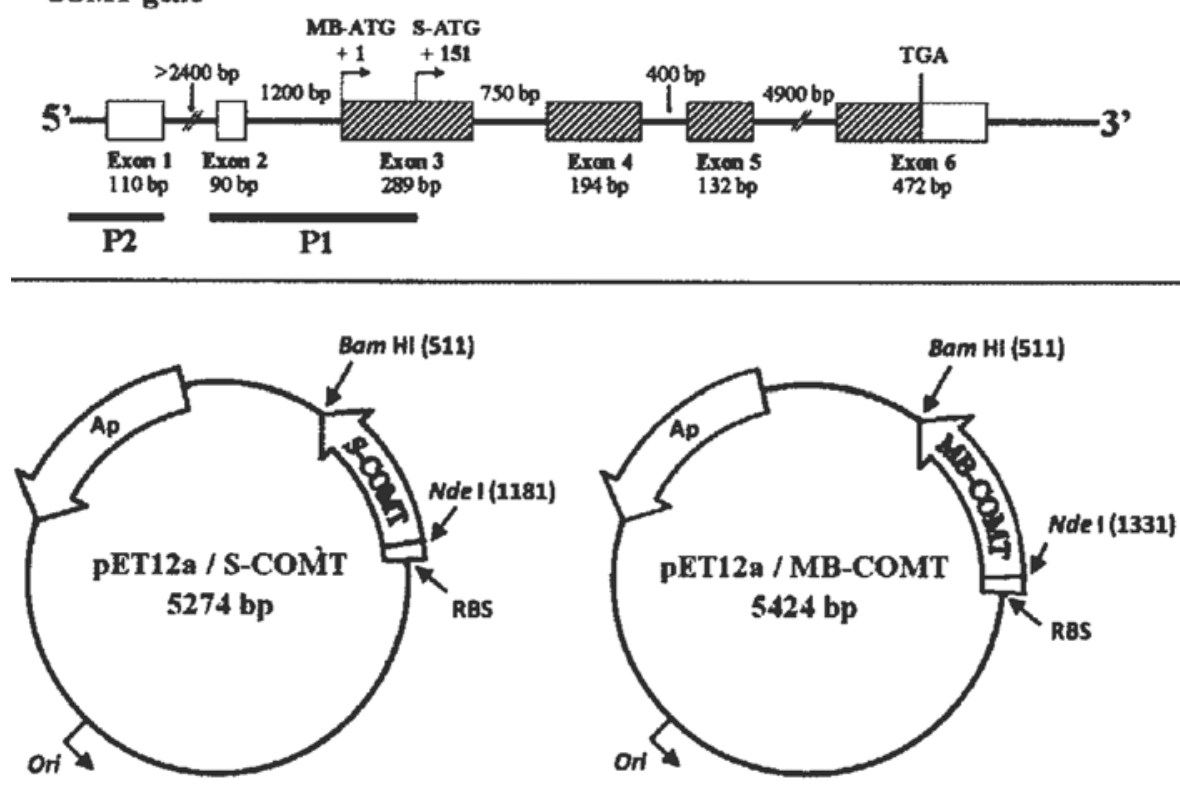

Figure 1. Upper panel: Structure of the human COMT gene. The boxes represent exons and the thin lines between the boxes represent introns. The hatched boxes indicate protein-coding regions. The size of each exon and intron is as indicated. The positions of the initiation codons for the transcription of S-COMT and MB-COMT mRNAs are indicated as S-ATG and MB-ATG. The two known promoters, P1 and P2, are shown by black bars. Note that the P1 promoter for transcritpion of S-COMT overlaps with the initiation codon and part of the coding sequence for MB-COMT. Lower panel: Construction of the pET12a/SCOMT and pET12a/MB-COMT expression vectors based on the vector pET12a. The S-COMT or MB-COMT cDNA was cloned into the NdeI and BamH I sites of pET12a to form the pET12a/S-COMT or pET12a/MB-COMT expression vectors. Each of the expression vectors was under the control of the T7 promoter and lacO-operator. Expression was induced by the addition of $0.5 \mathrm{mM}$ isopropylthio- $\beta$ - $D$-galactoside.

DNAs were introduced into chemically competent $E$. coli BL21 (DE3) (Novagen, Madison, WI) according to the procedures recommended by the manufacturer, and the transformed cells were selected with ampicillin $(50 \mu \mathrm{g} / \mathrm{ml})$ on LB agar plates.

In vitro site-directed mutagenesis. The cDNAs of the cloned mutant human S-COMT (D51G, S60F and K162R) and MBCOMT (D101G, S110F and K212R) were used as templates to generate the corresponding wild-type cDNAs. The mutations were corrected by using a PCR-based site-directed mutagenesis using the QuikChange multisite-directed mutagenesis kit (Stratagene, La Jolla, CA). The site-directed mutagenesis was carried out according to the procedures recommended by the manufacturer with the following primers: 5'-GGCAAGATCGTGGACGCCGTGATTC-3' for D51/101G, 5'-CACCAGCCCTCCGTGCTGCTGGAGC-3' for S60/110F, and 5'-CTGCTGCGGAAGGGGACAGTGC TAC-3' for K162/212R. The sequences of reconstructed plasmid DNAs were confirmed by DNA sequencing.

Bacterial expression of recombinant human COMTs. For the expression of the recombinant human S- and MB-COMT proteins in E. coli BL21 (DE3, expressing T7 polymerase), positive clones were first cultured in the LB medium supplemented with ampicillin $(50 \mu \mathrm{g} / \mathrm{ml})$ overnight at $37^{\circ} \mathrm{C}$. The culture broth was then inoculated into $300 \mathrm{ml}$ fresh $\mathrm{LB}$ medium supplemented with ampicillin and incubated at $37^{\circ} \mathrm{C}$ with vigorous shaking until the optical density reading of the bacterial culture mixture achieved $\sim 0.6$ (at $\lambda=600 \mathrm{~nm}$ ). The culture was then induced with isopropylthio- $\beta$-D-galactoside (at a final concentration of $0.5 \mathrm{mM}$ ) and cultured for another
$3 \mathrm{~h}$. The cells were collected by centrifugation and were then sonicated in ice-cold lysis buffer (50 mM Tris- $\mathrm{HCl}, \mathrm{pH} 7.5+$ $200 \mathrm{mM} \mathrm{NaCl}$ ). After the addition of $5 \mathrm{mM} \mathrm{1,4-dithiothreitol}$ and $1 \mathrm{mM}$ phenylmethylsulfonyl fluoride to the crude homogenates, they were centrifuged at $10,000 \mathrm{x} g$ for $10 \mathrm{~min}$ at $4^{\circ} \mathrm{C}$. The supernatants were then subjected to column purification or directly stored at $-80^{\circ} \mathrm{C}$.

Assay of the enzyme activity and thermostability of recombinant human COMTs in vitro. The catalytic activity of the wild-type and mutant human recombinant $\mathrm{S}$ - and MBCOMTs was determined at $37^{\circ} \mathrm{C}$ as described earlier (38). The reaction mixtures consisted of the recombinant COMT protein (at $16.2 \mu \mathrm{g} / \mathrm{ml}$ for S-COMT or $17.1 \mu \mathrm{g} / \mathrm{ml}$ for MBCOMT), $1.2 \mathrm{mM} \mathrm{MgCl} 2,100 \mu \mathrm{M}$ AdoMet (containing $0.5 \mathrm{mCi}$ [methyl- ${ }^{3} \mathrm{H}$ ]AdoMet), $1 \mathrm{mM} \mathrm{1,4-dithiothreitol,} \mathrm{and} \mathrm{2-OH-E_{2 }}$ or $4-\mathrm{OH}-\mathrm{E}_{2}$ as substrate (at $10 \mu \mathrm{M}$ or as indicated) in Tris$\mathrm{HCl}$ buffer (50 mM, pH 7.4). The final volume of the reaction mixture was $300 \mu 1$. The reaction was initiated by the addition of recombinant human COMT protein and carried out at $37^{\circ} \mathrm{C}$ for $15 \mathrm{~min}$. To test the thermo-stability of the mutant and wild-type COMTs, the enzymes were first preincubated at $37^{\circ} \mathrm{C}$ for the indicated length of time immediately before testing their catalytic activity for the $O$ methylation of $2-\mathrm{OH}-\mathrm{E}_{2}$ (at $10 \mu \mathrm{M}$ ). The reaction was arrested by immediately placing the tubes on ice and followed by addition of $500 \mu 1$ ice-cold saline. The reaction mixtures were extracted with $5 \mathrm{ml}$ ethyl acetate for the methylated catechol products. After centrifugation at $1000 \mathrm{~g}$ for $10 \mathrm{~min}$, portions of the organic extracts were measured for radioactivity content with a liquid scintillation analyzer (Packard Tri-CARB 2900TR, Downers Grove, IL). The rate 
of methylation of a substrate was expressed as "nmol of methylated product formed/mg of human COMT protein/ minute' (abbreviated as ' $\mathrm{nmol} / \mathrm{mg}$ protein/min'). The kinetic parameters $\left(\mathrm{K}_{\mathrm{M}}\right.$ and $\mathrm{V}_{\mathrm{MAX}}$ values) were calculated by using the curve regression method of the SigmaPlot program.

Construction of the homology models for human wild-type and mutant S-COMTs. Homology modeling was performed using the InsightII modeling program (Version 2005, Accelrys Inc., San Diego, CA) on a Dell Precision 690 workstation installed with Red Hat Enterprise Linux WS4.0 operating system (Red Hat Inc., Raleigh, NC). The energy minimization and molecular dynamics simulation were performed with Discovery Studio modeling program (Version 1.7, Accelrys Inc., San Diego, CA). The CHARMm force field was used for energy minimization and dynamics simulation.

The primary sequences of human S-COMT (GeneBank accession no. NM007310) and rat S-COMT (GeneBank accession no. BC081850) were obtained from the NCBI database. Sequence alignments were performed by using the Homology Modeling module of InsightII, which showed a $\geq 80 \%$ sequence similarity. The homology model of the human S-COMT was constructed according to the rat SCOMT (PDB code: 1VID) by using the Modeler in the Homology Modeling module of InsightII. The substrate 3,5dinitrocatechol, AdoMet, $\mathrm{Mg}^{2+}$ ion, and the crystallographic $\mathrm{H}_{2} \mathrm{O}$ that coordinates with $\mathrm{Mg}^{2+}$ were included in the homology model. The simulation was carried out using the Standard Dynamics Cascade protocol in the Discovery Studio. For energy minimization, the steepest descent method was employed first to a $10 \mathrm{kcal} /(\mathrm{mol} \AA)$ root mean square gradient and followed by the Polak and Ribiere conjugate gradient method until the final convergence criterion achieved $0.01 \mathrm{kcal} /(\mathrm{mol} \AA)$ gradient. Then the whole system was heated from 50 to $300 \mathrm{~K}$ in 2 ps and equilibrated in 300 $\mathrm{K}$ for $100 \mathrm{ps}$. One hundred conformations were collected in 20 -ps production phase at $300 \mathrm{~K}$. The conformation with the lowest potential energy was further minimized and used for binding energy analysis. 3,5-Dinitrocatechol, $\mathrm{Mg}^{2+}, \mathrm{H}_{2} \mathrm{O}$, AdoMet and key residues in the catalytic site (D141, K144, D169, N170 and E199) were constrained during the simulation process.

It should be noted that the structure of the D51G/ S60F/K162R mutant human S-COMT was built with the Build Mutant function of the Homology Modeling module by using two different methods: one was based on the homology model of the wild-type human S-COMT that was built in the present study and the other was based on the crystallographic structure of the rat S-COMT (PDB code: 1VID). The same simulation process was carried out when we built the structures of the mutant or wild-type S-COMT.

Calculation of the binding energy values $\left(\Delta E_{\text {binding }}\right)$ of $S$ COMTs with substrates. The structures of $2-\mathrm{OH}-\mathrm{E}_{2}$ and 4$\mathrm{OH}-\mathrm{E}_{2}$ were built with the Builder module of InsightII based on the X-ray structure of $\mathrm{E}_{2}$ (PDB code: 1ERE) and minimized with CHARMm force field. The catechol ring of the substrates was superimposed onto the catechol ring of 3,5dinitrocatechol. The simulation was carried out with the
Standard Dynamics Cascade protocol in Discovery Studio. The same simulation cascade was carried out as the cascade that was used for building the human COMT in complex with 3,5-dinitro-catechol as ligand. One hundred conformations were collected in the 20-ps production phase at $300 \mathrm{~K}$. The conformation with the lowest potential energy was further minimized and used for the Binding Energy Calculation protocol. The backbone of the protein, key residues in the catalytic site (D141, K144, D169, N170 and E199), the catechol ring of the substrate, AdoMet, $\mathrm{Mg}^{2+}$, and $\mathrm{H}_{2} \mathrm{O}$ were constrained during the whole simulation process. $\Delta E_{\text {binding }}$ was calculated with the following equation: $\Delta E_{\text {binding }}$ $=E_{\text {complex }}-\left(E_{\text {COMT }}+E_{\text {substrate }}\right)$, where $E_{\text {complex }}$ is the potential energy for the complex of human COMT with its substrate, $E_{\text {Сомт }}$ is the potential energy of the enzyme itself and $E_{\text {substrate }}$ is the potential energy for the substrate itself.

\section{Results}

Cloning of the mutant human $S$ - and MB-COMT cDNAs. In the present study, the human S- and MB-COMT cDNAs were selectively amplified with PCR using the human liver cDNA library as a template. After the recombinant plasmids containing the cDNA for human S-COMT or MB-COMT were enzymatically digested, gel electrophoresis of the digests revealed that the DNA fragment bands matched the expected sizes of 655 and $815 \mathrm{bp}$, respectively (data not shown). The full-length sequence analysis of the cloned cDNAs was performed to determine their sequences. By comparing with sequences of NM_000754 and NM_007310, which were used as standards for the wild-type human SCOMT and MB-COMT, respectively, we found that the sequences were changed at three places for S-COMT and MB-COMT cDNAs, and the changes were at the same positions for the two of them. As noted earlier, three different types of DNA polymerase, each with high fidelity and proofreading capability, were used in this study for the PCR for cloning the human $S$-COMT and MB-COMT cDNAs. The resulting cDNA products from three different DNA polymerases were sequenced and the same sequence was obtained. Notably, since it is known that a single gene [localized to chromosome 22, band q11.2 $(8,9)$ ] encodes human S- and MB-COMT proteins by using two separate promoters (6), we believe that the triplet point mutations of the human S- and MB-COMT cDNAs were not artificial errors produced during the cloning procedures, as the exact same triplet point mutations were seen in the cDNAs of SCOMT (D51G/S60F/K162R) and MB-COMT (D101G/ $\mathrm{S} 110 \mathrm{~F} / \mathrm{K} 212 \mathrm{R})$. The likelihood of their occurrence as a result of experimental errors was very low.

To obtain the wild-type human S- and MB-COMT cDNAs, we carried out PCR-based site-directed mutagenesis based on the mutant human S- and MB-COMT cDNAs. The full-length DNA sequences were determined twice and compared with the known wild-type human COMT gene. The DNA sequencing results confirmed their right sequences.

Expression of the mutant and wild-type COMT proteins in $E$. coli. The E. coli BL21 (DE3) cells were transformed with the recombinant expression vector $\mathrm{pET} 12 \mathrm{a}$ containing the gene 


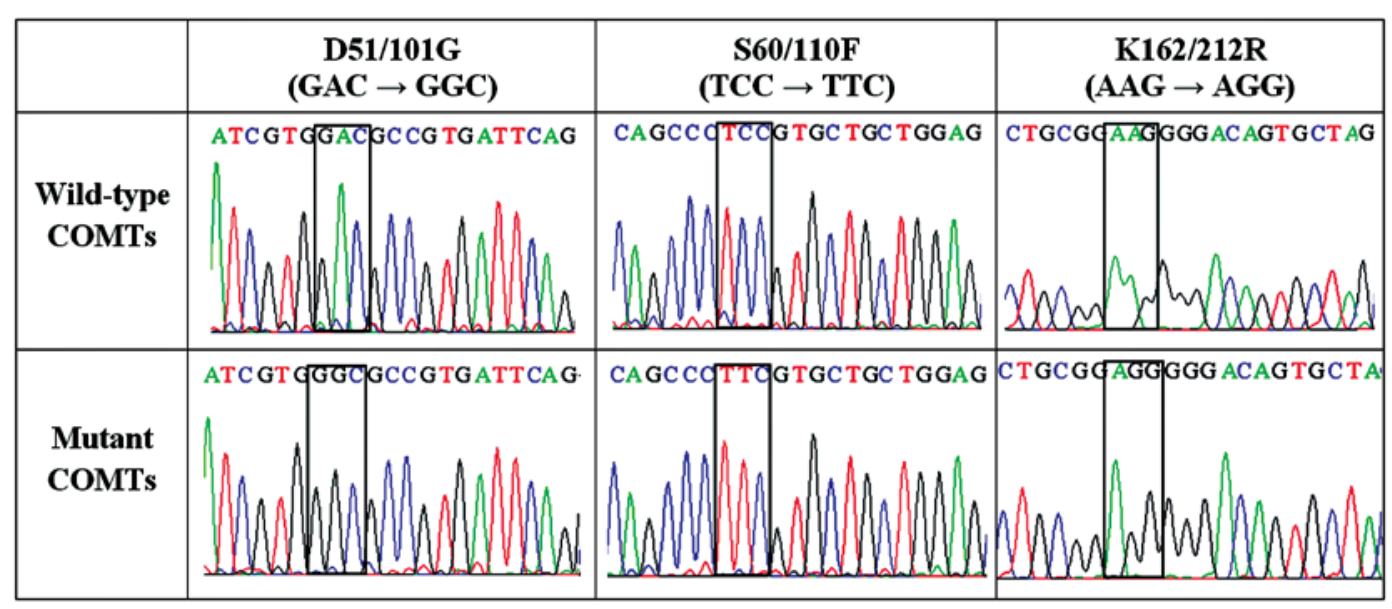

Figure 2. Sequencing results of the wild-type and haplotype human S- and MB-COMTs.

Table II. A comparison of the kinetic parameters of the mutant forms of the human S- and MB-COMTs with those of wildtype human S- and MB-COMTs.

\begin{tabular}{|c|c|c|c|c|c|}
\hline Genotype & Substrate $(\mu \mathrm{M})$ & AdoMet $(\mu \mathrm{M})$ & $K_{\mathrm{M}}(\mu \mathrm{M})$ & $\begin{array}{c}V_{\mathrm{MAX}} \\
(\mathrm{nmol} / \mathrm{mg} / \mathrm{min})\end{array}$ & $V_{\mathrm{MAX}} / K_{\mathrm{M}}$ \\
\hline \multicolumn{6}{|c|}{ Wild-type COMT } \\
\hline $\begin{array}{l}\text { S-COMT } \\
\text { MB-COMT }\end{array}$ & $\begin{array}{l}2-\mathrm{OH}-\mathrm{E}_{2}(0-80) \\
4-\mathrm{OH}-\mathrm{E}_{2}(0-80) \\
2-\mathrm{OH}-\mathrm{E}_{2}(0-80) \\
4-\mathrm{OH}-\mathrm{E}_{2}(0-80)\end{array}$ & $\begin{array}{l}100 \\
100 \\
100 \\
100\end{array}$ & $\begin{array}{l}3.6 \\
4.5 \\
3.2 \\
6.4\end{array}$ & $\begin{array}{r}9.7 \\
3.5 \\
16.3 \\
14.3\end{array}$ & $\begin{array}{l}2.7 \\
0.8 \\
5.1 \\
2.2\end{array}$ \\
\hline \multicolumn{6}{|c|}{$\begin{array}{l}\text { Mutant COMT } \\
\text { (D51G/S60F/K162R) } \\
\text { Enzyme: }\end{array}$} \\
\hline S-COMT & $\begin{array}{l}2-\mathrm{OH}-\mathrm{E}_{2}(0-80) \\
4-\mathrm{OH}-\mathrm{E}_{2}(0-80) \\
2-\mathrm{OH}-\mathrm{E}_{2}(0-80) \\
4-\mathrm{OH}-\mathrm{E}_{2}(0-80)\end{array}$ & $\begin{array}{l}100 \\
100 \\
100 \\
100\end{array}$ & $\begin{array}{l}3.3 \\
4.5 \\
2.6 \\
5.0\end{array}$ & $\begin{array}{r}8.7 \\
3.5 \\
16.1 \\
14.1\end{array}$ & $\begin{array}{l}2.6 \\
0.8 \\
6.2 \\
2.8\end{array}$ \\
\hline \multicolumn{6}{|c|}{ Wild-type COMT } \\
\hline S-COMT & $\begin{array}{l}2-\mathrm{OH}-\mathrm{E}_{2}(10) \\
4-\mathrm{OH}-\mathrm{E}_{2}(10)\end{array}$ & $\begin{array}{l}0-400 \\
0-400\end{array}$ & $\begin{array}{l}113.6^{\mathrm{a}} \\
145.3^{\mathrm{a}}\end{array}$ & $\begin{array}{l}18.3^{\mathrm{a}} \\
17.1^{\mathrm{a}}\end{array}$ & - \\
\hline \multicolumn{6}{|c|}{$\begin{array}{l}\text { Mutant COMT } \\
\text { (D51G/S60F/K162R) } \\
\text { Enzyme: }\end{array}$} \\
\hline S-COMT & $\begin{array}{l}2-\mathrm{OH}-\mathrm{E}_{2}(10) \\
4-\mathrm{OH}-\mathrm{E}_{2}(10)\end{array}$ & $\begin{array}{l}0-400 \\
0-400\end{array}$ & $\begin{array}{r}79.5^{\mathrm{a}} \\
146.7^{\mathrm{a}}\end{array}$ & $\begin{array}{r}18.1^{\mathrm{a}} \\
9.6^{\mathrm{a}}\end{array}$ & $\begin{array}{l}- \\
-\end{array}$ \\
\hline
\end{tabular}

aTo determine the apparent $K_{\mathrm{M}}$ and $V_{\mathrm{MAX}}$ values of AdoMet for the $O$-methylation catalyzed by S-COMT and MB-COMT, a fixed concentration (at $10 \mu \mathrm{M}$ ) of $2-\mathrm{OH}-\mathrm{E}_{2}$ or $4-\mathrm{OH}-\mathrm{E}_{2}$ was used as a substrate, and different concentrations of AdoMed (at 0, 12.5, 25, 50, 100, 200 , and $400 \mu \mathrm{M}$ ) were used as the methyl donor.

encoding either the mutant or wild-type human S-COMT or MB-COMT. Following induction with $0.5 \mathrm{mM}$ isopropylthio$\beta$ - $D$-galactoside, the bacteria that abundantly expressed the desired protein were harvested by centrifugation. The resulting cell pellets were lysed and analyzed using 12\% SDS-PAGE, followed by Western blot analysis using polyclonal rabbit antibodies against the human wild-type COMT and donkey anti-rabbit IgG antiserum (conjugated to horseradish peroxidase).
A band with a molecular mass of $\sim 24 \mathrm{kD}$ was detected for mutant and wild-type S-COMT proteins, and a band of $\sim 30 \mathrm{kD}$ was detected for the mutant and wild-type MB-COMTs (data not shown). The sizes of the expressed proteins matched the expected sizes for the recombinant human S- and MBCOMT proteins.

Kinetic parameters for the $\mathrm{O}$-methylation of $2-\mathrm{OH}-\mathrm{E}_{2}$ and 4-OH- $E_{2}$. To characterize the kinetic parameters $\left(\mathrm{K}_{\mathrm{M}}, \mathrm{V}_{\mathrm{MAX}}\right.$ 
Wild-type S-COMT

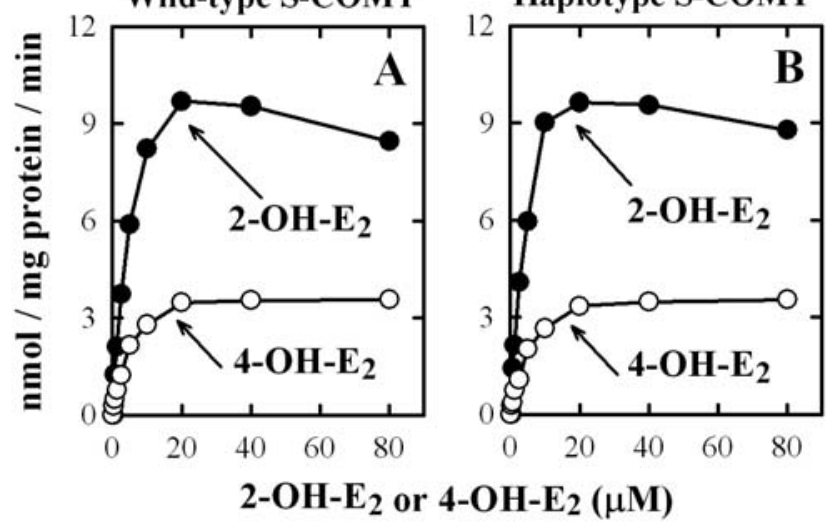

Wild-typeMB-COMT

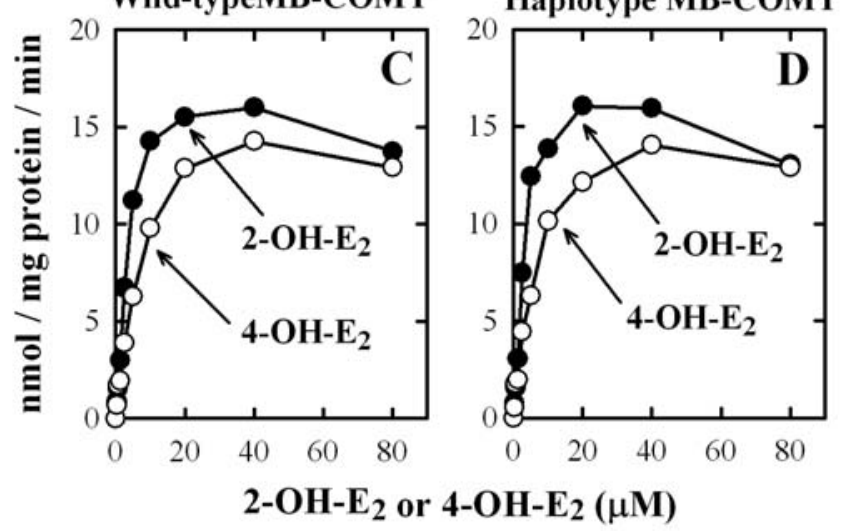

Wild-type S-COMT

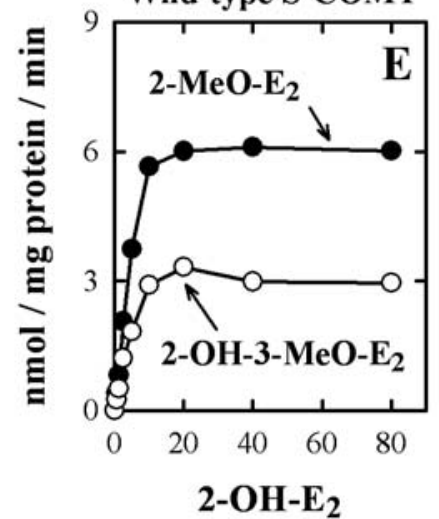

Haplotype S-COMT

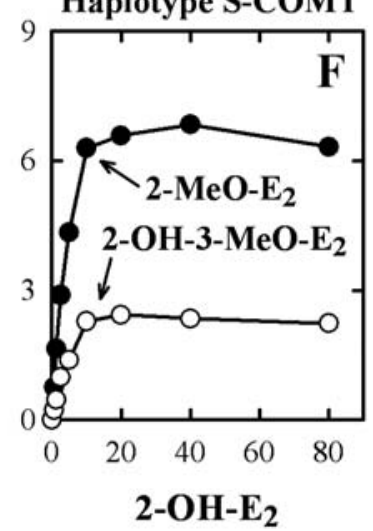

Figure 3. Relationship between catechol estrogen concentrations and their rate of $O$-methylation by wild-type human COMTs (A, C and E) and the haplotype COMTs (B, D, and F). Panel E shows the rate of 2- $O$-methylation and $3-O-$ methylation of $2-\mathrm{OH}-\mathrm{E}_{2}$ catalyzed by the wild-type S-COMT, and panel $\mathrm{F}$ shows the rate of 2-O-methylation and 3-O-methylation of $2-\mathrm{OH}-\mathrm{E}_{2}$ by mutant S-COMT. The incubation mixture consisted of 10 different concentrations $(0,0.31,0.63,1.25,2.5,5,10,20,40$, and $80 \mu \mathrm{M})$ of each substrate, $1.2 \mathrm{mM} \mathrm{MgCl}, 100 \mu \mathrm{M}$ AdoMet (containing $0.5 \mathrm{mCi}$ [methyl${ }^{3} \mathrm{H}$ ]AdoMet), $1 \mathrm{mM}$ 1,4-dithiothreitol, and the recombinant COMT protein (at $16.2 \mu \mathrm{g} / \mathrm{ml}$ for S-COMT or $17.1 \mu \mathrm{g} / \mathrm{ml}$ for MB-COMT). The incubations were carried out at $37^{\circ} \mathrm{C}$ for $15 \mathrm{~min}$. Note that the rate of its total methylation was based on the liquid scintillation counting of the radioactivity extracted with ethyl acetate. The rates for its 2-O- and 3-Omethylation ( $\mathrm{C}$ and $\mathrm{F}$ ) were determined by using HPLC that separately quantified the amount of 2-methoxyestradiol (2-MeO- $\left.\mathrm{E}_{2}\right)$ and $2-\mathrm{OH}-\mathrm{E}_{2} 3-$ methyl ether (2-OH-3-MeO- $\mathrm{E}_{2}$ ) formed. Each value is the mean of duplicate measurements. and $\mathrm{V}_{\mathrm{MAX}} / \mathrm{K}_{\mathrm{M}}$ ) of the mutant human S- and MB-COMTs, we selectively expressed them and also the wild-type S- and MB-COMTs in E. coli. The enzyme activity assays were performed by measuring the COMT-mediated $O$-methylation of $2-\mathrm{OH}-\mathrm{E}_{2}$ and $4-\mathrm{OH}-\mathrm{E}_{2}$, two representative endogenous catechol estrogen substrates. No significant difference was observed between the wild-type S-COMT and its D51G/ S60F/K162R mutant form, or between the wild-type MBCOMT and its D101G/S110F/K212R mutant form (Fig. 2 and Table II).

When a fixed concentration of $2-\mathrm{OH}-\mathrm{E}_{2}$ or $4-\mathrm{OH}-\mathrm{E}_{2}$ (at $10 \mu \mathrm{M}$ ) was used as a substrate, the apparent $\mathrm{K}_{\mathrm{M}}$ values of the wild-type S-COMT for AdoMet were 113.6 or $145.3 \mu \mathrm{M}$, respectively (Fig. 3). Under the same conditions, the apparent $\mathrm{K}_{\mathrm{M}}$ values of the D51G/S60F/K162R mutant of human SCOMT for AdoMet were 79.5 and $146.7 \mu \mathrm{M}$. Notably, the $\mathrm{K}_{\mathrm{M}}$ value of the mutant S-COMT for AdoMet in the $O$ methylation of $2-\mathrm{OH}-\mathrm{E}_{2}$ (but not $4-\mathrm{OH}-\mathrm{E}_{2}$ ) was $\sim 50 \%$ lower than the corresponding $\mathrm{K}_{\mathrm{M}}$ value for the wild-type $\mathrm{S}-\mathrm{COMT}$ (Table II).

We have also compared the sensitivity of the mutant and wild-type human S-COMTs to inhibition by AdoHcy (a physiological feedback inhibitor of COMTs) on the $O$ methylation of $2-\mathrm{OH}-\mathrm{E}_{2}$ and $4-\mathrm{OH}-\mathrm{E}_{2}$. The mutant D51G/S60F/K162R S-COMT was less sensitive to inhibition by AdoHcy for the $\mathrm{O}$-methylation of $2-\mathrm{OH}-\mathrm{E}_{2}$ as compared to the wild-type S-COMT $\left(I C_{50}\right.$ values of 18.4 and $6.07 \mu \mathrm{M}$, respectively, Fig. 4). However, AdoHcy had a comparable potency for inhibiting the $O$-methylation of $4-\mathrm{OH}-\mathrm{E}_{2}$ by the wild-type S-COMT and its D51G/S60F/K162R mutant (the $I C_{50}$ values of 22.6 and $29.6 \mu \mathrm{M}$, respectively) (Fig. 4).

Thermostability test. The thermostability of human COMTs has often been used as an indicator of the biophysical properties of the mutant COMT proteins. In the present study, we also compared the thermostability of the mutant human S- and MB-COMTs with the wild-type COMTs. The D5 $1 \mathrm{G} / \mathrm{S} 60 \mathrm{~F} / \mathrm{K} 162 \mathrm{R}$ mutant S-COMT and the D $101 \mathrm{G} /$ S110F/K212R mutant MB-COMT were more sensitive to inactivation after pre-incubation at $37^{\circ} \mathrm{C}$. The mutant SCOMT and MB-COMT lost $\sim 60 \%$ of their catalytic activity after pre-incubation at $37^{\circ} \mathrm{C}$ for $120 \mathrm{~min}$, while the wild-type enzymes were mostly stable after up to $120 \mathrm{~min}$ of preincubation at $37^{\circ} \mathrm{C}$ (Fig. 5).

Notably, the thermostability of the S60F/K 162R mutant $\mathrm{S}$-COMT, which has one of the three point mutations corrected by site-directed mutagenesis, was completely restored to that of the wild-type COMT (data not shown). These data showed that the aspartate residue at position 51 (D51) of the human S-COMT plays a crucial role in determining its thermostability.

Molecular modeling. To better understand the mechanism of the triplet point mutations in affecting the structure and catalytic activity of human COMTs, we constructed the homology models for wild-type and mutant human SCOMTs. Two different methods were used to build the mutant human S-COMT. One of them used the human SCOMT homology model as a template to build the structure 
A

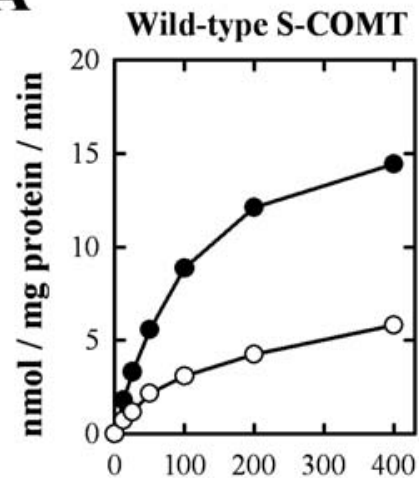

AdoMet $(\mu \mathbf{M})$

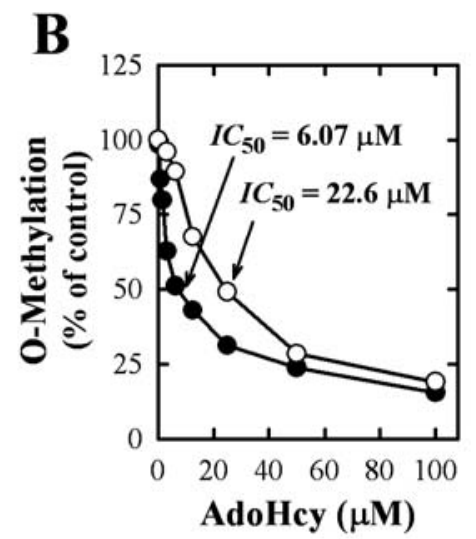

$\longrightarrow-2-\mathrm{OH}-\mathrm{E}_{2}$

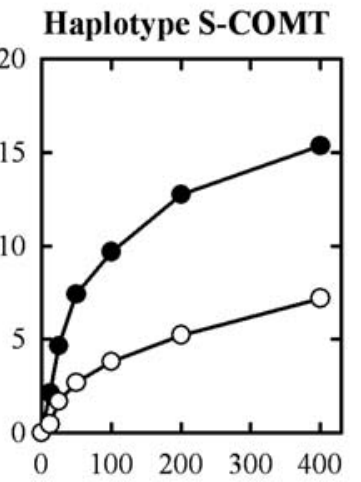

AdoMet $(\mu \mathrm{M})$

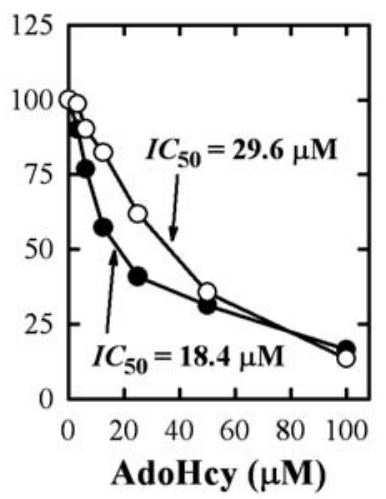

4-OH-E

Figure 4. Biochemical properties of the in vitro $O$-methylation of catechol substrates with respect to AdoMet and AdoHcy concentrations. The representative substrates used in these assays were $2-\mathrm{OH}-\mathrm{E}_{2}$ and $4-\mathrm{OH}-\mathrm{E}_{2}$ at $10 \mu \mathrm{M}$ concentrations. The incubation mixture consisted of the substrate, $100 \mu \mathrm{M}$ [methyl- ${ }^{3} \mathrm{H}$ ]AdoMet (containing $0.2 \mu \mathrm{Ci}$ or as indicated), $16.2 \mu \mathrm{g} / \mathrm{ml}$ of wild-type S-COMT or haplotype S-COMT, $1 \mathrm{mM} \mathrm{1,4-dithiothreitol,} \mathrm{and}$ $1.2 \mathrm{mM} \mathrm{MgCl}{ }_{2}$ in a final volume of $300 \mu 1$ Tris- $\mathrm{HCl}$ buffer $(50 \mathrm{mM})$ at $\mathrm{pH} 7.4$. The incubations were carried out at $37^{\circ} \mathrm{C}$ for $15 \mathrm{~min}$. Each value is the mean of duplicate measurements.

of the mutant S-COMT. This method has been commonly used in many other similar studies. In addition, we also built de novo the structure of the mutant human S-COMT according to the known crystallographic structure of the rat S-COMT. The use of two different methods was hoped to provide a more complete view of the possible structures of this new mutant human COMT. Our homology models showed that the two mutant S-COMT homology models built with two different templates are nearly the same in their backbone structures as well as their catalytic sites (Fig. 6), with only minor differences in the side-chain orientations. Therefore, for further structural comparison with the wildtype human S-COMT as well as for docking calculations using representative substrates, the mutant S-COMT built according to the wild-type human S-COMT was used.

When the enzyme was complexed with a representative substrate and also the methyl donor AdoMet, the secondary structures of the wild-type and mutant S-COMTs were nearly identical (Fig. 6). Although the S60F mutation caused some minor changes in loop 5 which connects $\alpha$-helix 4 and $\beta$ -
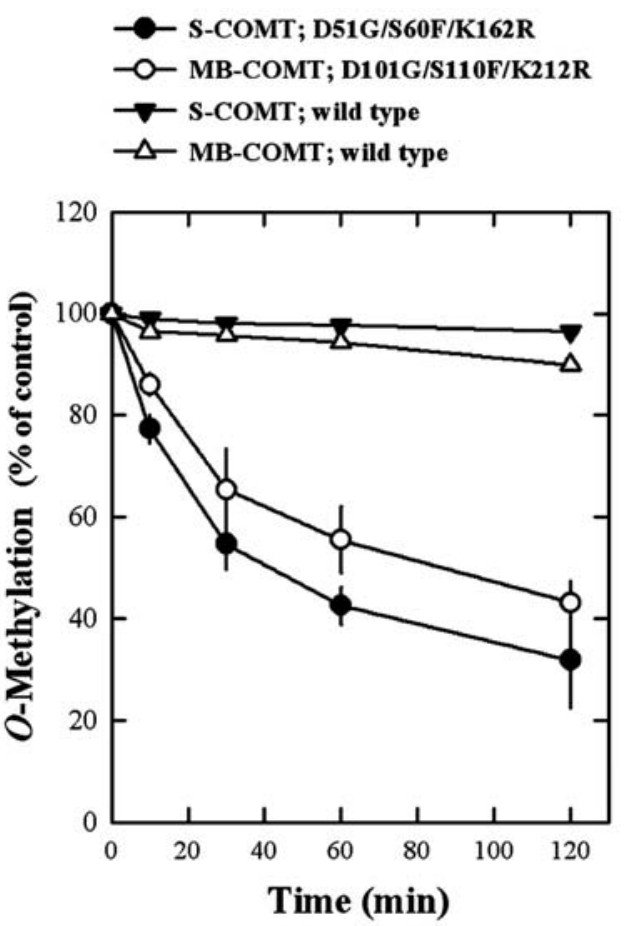

Figure 5. Stabilities of the wild-type and haplotype human recombinant Sand MB-COMTs. The reaction mixtures consisted of the recombinant COMT protein (at $16.2 \mu \mathrm{g} / \mathrm{ml}$ for S-COMT or $17.1 \mu \mathrm{g} / \mathrm{ml}$ for MB-COMT), $1.2 \mathrm{mM} \mathrm{MgCl} \mathrm{M}_{2}, 100 \mu \mathrm{M}$ AdoMet (containing 0.5-1 mCi [methyl${ }^{3} \mathrm{H}$ ]AdoMet), 2-OH-E $\mathrm{E}_{2}$ as a substrate and $1 \mathrm{mM}$ 1,4-dithiothreitol in Tris$\mathrm{HCl}$ buffer $(50 \mathrm{mM}, \mathrm{pH} 7.4)$. The final volume of the reaction mixture was usually $300 \mu 1$. The reaction was initiated by the addition of the recombinant human COMT protein and carried out at $37^{\circ} \mathrm{C}$ for $15 \mathrm{~min}$. To test the thermostability of the mutant and wild-type COMTs, the enzymes were first preincubated at $37^{\circ} \mathrm{C}$ for the indicated length of time immediately before testing their catalytic activity for the $O$-methylation of $2-\mathrm{OH}-\mathrm{E}_{2}$ (at $10 \mu \mathrm{M}$ ). Each value is the mean \pm S.D. of triplicate measurements.

sheet 2 , the overall structure and configuration of the nine $\alpha$ helixes and seven $\beta$-sheets remained mostly the same. The amino acid residue D51 in the wild-type S-COMT was located in $\alpha$-helix 3, and S60 and K162 were located in two different loop regions (loops 3 and 11, respectively). A comparison of homology-modeled structures of the wild-type and mutant form showed that the D51G mutation did not noticeably interrupt the structure of $\alpha$-helix 3 of the enzyme, and similarly, the S60K and K162R mutations also did not significantly affect the overall structure of the enzyme. Notably, these three mutations are mostly located in the outer surface regions of the COMT protein, and they are on the opposite side of the catalytic pocket. The distances between the $\alpha$-carbon of D51, S60 and $\mathrm{K} 162$ to $\mathrm{Mg}^{2+}$ are $13.8,23.2$ and $25.2 \AA$, respectively, which are beyond the defined catalytic site (within the $7-\AA$ reach of the $\mathrm{Mg}^{2+}$ ion). The structures of the catalytic sites in the wild-type and mutant COMTs are nearly identical when they are in complex with $2-\mathrm{OH}-\mathrm{E}_{2}$ or $4-\mathrm{OH}-\mathrm{E}_{2}$. In addition, the orientations of the two substrates are very similar when they are bound as a substrate in the catalytic pocket.

Using the homology models we developed, we also computed the relative binding energy values $\left(\Delta E_{\text {binding }}\right)$ of the wild-type and mutant human COMTs for 2-OH-E 2 and 4$\mathrm{OH}-\mathrm{E}_{2}$. We found that $2-\mathrm{OH}-\mathrm{E}_{2}$ and $4-\mathrm{OH}-\mathrm{E}_{2}$ have similar 

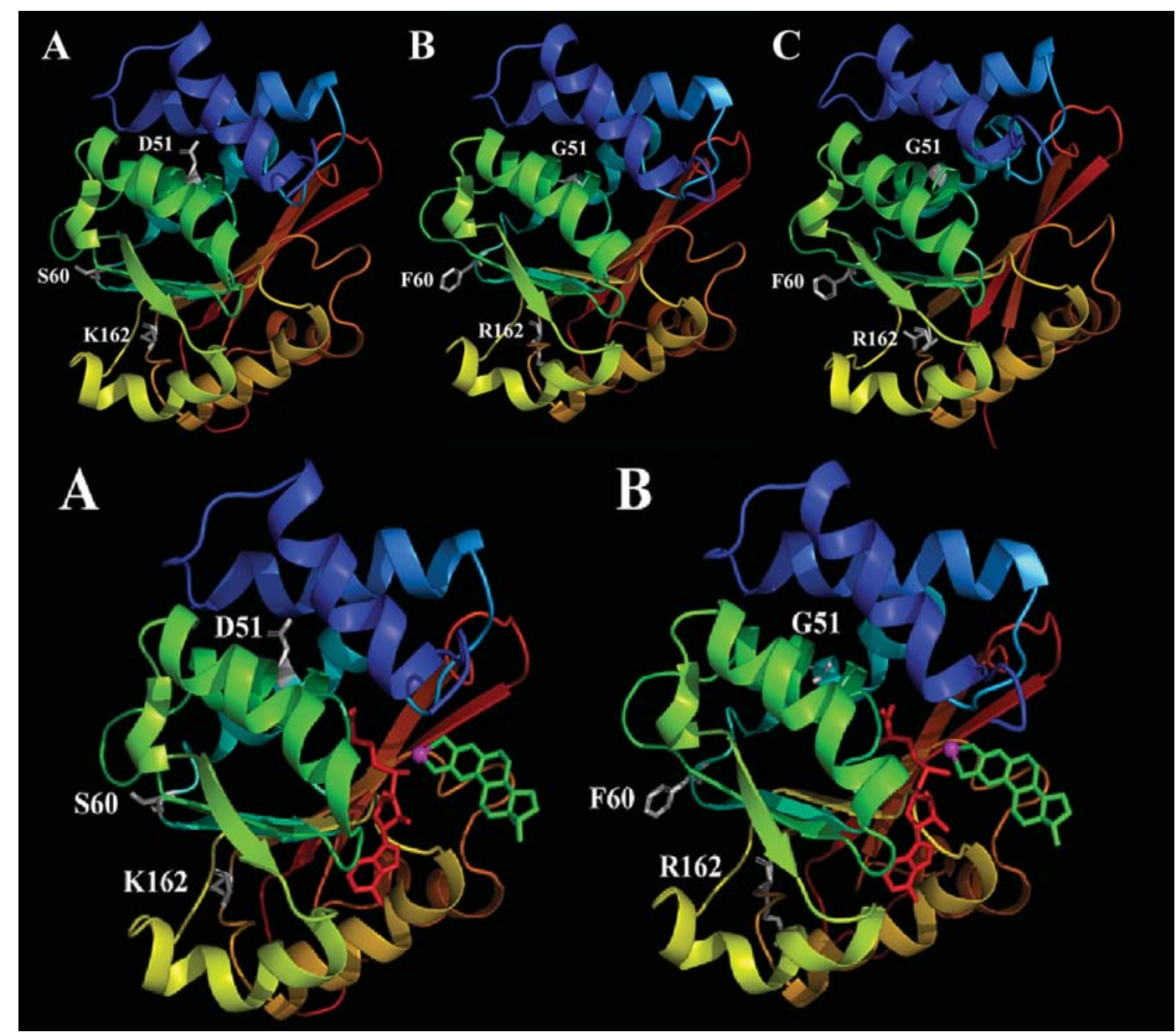

Figure 6. Computational molecular modeling analysis of the wild-type and new haplotype human COMT structures. Upper panel. The homology models of the wild-type human S-COMT (A), the D51G/S60F/K162R mutant S-COMT built according to the homology model of the wild-type human S-COMT (B), or according to the crystallographic structure of the rat S-COMT (PDB code: 1VID) (C). Note that AdoMet, $\mathrm{Mg}^{2+}$ and substrates are not included in the development of this initial homology model. The figure is drawn with the PyMOL software. Secondary structures are shown with colored ribbons with blue for $N$-terminus and red for $C$-terminus. The amino acids at mutation sites (D51, S60 and K162 for wild-type S-COMT and G51, F60 and R162 for mutant SCOMT) are shown in white sticks. Hydrogens are omitted from the amino acids. Lower panel. The homology models of the wild-type human S-COMT (A) and the D51G/S60F/K162R mutant S-COMT (built according to the homology model of the wild-type human S-COMT) (B) in the presence of AdoMet, Mg²+ and a representative substrate $\left(2-\mathrm{OH}-\mathrm{E}_{2}\right)$. The enzymes are complexed with $2-\mathrm{OH}-\mathrm{E}_{2}$ in the catalytic pocket in its geometry for 2-O-methylation. The figure is drawn using PyMOL software. Secondary structures are shown with colored ribbons with blue for $N$-terminus and red for $C$-terminus. AdoMet is colored red, 2-OH- $\mathrm{E}_{2}$, green and $\mathrm{Mg}^{2+}$, magenta. The amino acids at mutation sites (D51, S60 and K162 for wild-type S-COMT and G51, F60 and R162 for mutant SCOMT) are shown in white sticks. Hydrogens are omitted from AdoMet, 2-OH- $\mathrm{E}_{2}$ and the amino acids.

binding energy values for the wild-type and mutant S-COMTs (data summarized in Table III). When 2-OH- $\mathrm{E}_{2}$ was the substrate, the $\Delta E_{\text {binding }}$ values for its interactions with the wild-type and mutant S-COMTs for its 2-O-methylation were relatively comparable, -124.5 and $-135.4 \mathrm{kcal} / \mathrm{mol}$, respectively (Table III), suggesting that the wild-type and mutant S-COMTs have a similar binding affinity for 2-OH$\mathrm{E}_{2}$, which agreed well with our experimental data (Table II). Similarly, the computed binding energy values for the binding interactions of $4-\mathrm{OH}-\mathrm{E}_{2}$ with the wild-type and mutant S-COMTs for its 4-O-methylation were -122.9 and $-138.5 \mathrm{kcal} / \mathrm{mol}$, respectively (Table III), which are also in agreement with our experimental data (Table II).

\section{Discussion}

Earlier familial studies based on the measurement of COMT activity in red blood cells revealed that COMT is a poly- morphic enzyme, with a bimodal/trimodel distribution pattern (39). Moreover, the trait of the low COMT activity was found to be associated with a decreased thermostability of the enzyme preparation (22-24). Following the subsequent cloning of the human COMT gene $(4,40,41)$, a number of single point mutations in the coding regions of this gene have been reported (listed in Table I). Among them, the V108/ $158 \mathrm{M}$ polymorphism has been most extensively studied. Many epidemiological studies have shown that women, homozygous with the V108/158M mutant, have an increased risk of developing estrogen-associated cancers (21-27). This polymorphism has also been suggested to be associated with an elevated risk of schizophrenia, obsessive-compulsive disorder, bipolar disorder, and Parkinson's disease in both genders $(22-24,28-32)$. In addition to the known effects associated with non-synonymous mutations, polymorphism involving synonymous changes (such as $\mathrm{H} 62 \mathrm{H}$ and L136L) has also been shown to cause a marked change in COMT 
Table III. The binding energy of 2-OH-E $\mathrm{E}_{2}$ and 4-OH-E $\mathrm{E}_{2}$ with the wild-type human S-COMT and the mutant S-COMT (D51G/S60F/K162R).

\begin{tabular}{lccc}
\hline Genotype & Substrate & Site of $O$-methylation & $\Delta E_{\text {binding }}$ \\
\hline Wild-type & $2-\mathrm{OH}-\mathrm{E}_{2}$ & $2-O$-methylation & -124.5 \\
& & $3-O$-methylation & -121.9 \\
& $4-\mathrm{OH}-\mathrm{E}_{2}$ & $3-O$-methylation & -122.9 \\
& & $4-O$-methylation & -123.2 \\
Mutant & & & -135.4 \\
(D51G/S60F/K162R) & $2-\mathrm{OH}-\mathrm{E}_{2}$ & $2-O$-methylation & -148.7 \\
& & $3-O$-methylation & -138.5 \\
& $4-\mathrm{OH}-\mathrm{E}_{2}$ & $3-O$-methylation & -143.4 \\
\hline
\end{tabular}

$\Delta E_{\text {binding }}$ was calculated using the following equation: $\Delta E_{\text {binding }}=E_{\text {complex }}-\left(E_{\mathrm{COMT}}+E_{\text {substrate }}\right)$, where $E_{\text {complex }}$ is the potentical energy for the complex of COMT with substrate, $E_{\mathrm{COMT}}$ is the potential energy of the enzyme itself and $E_{\text {substrate }}$ is the potential energy for the substrate itself.

levels, largely due to reduced amounts of the COMT proteins being expressed (12). These studies provide the basis for further studies to identify other non-synonymous and synonymous mutations/polymorphisms of the human COMT gene and particularly those that alter the catalytic activity of COMT and/or its protein levels.

In the present study, we identified a new haplotype of the human COMT gene with triplet point mutations (D51G/ S60F/K162R for S-COMT and D101G/S110F/ K212R for MB-COMT), and we have also selectively expressed the mutant enzymes in $E$. coli for the characterization of the catalytic properties. We found that the kinetic parameters $\left(\mathrm{K}_{\mathrm{M}}\right.$ and $\left.\mathrm{V}_{\mathrm{MAX}}\right)$ of the mutant $\mathrm{S}$ - and MB-COMTs did not differ significantly from those of the wild-type enzymes when $2-\mathrm{OH}-\mathrm{E}_{2}$ and $4-\mathrm{OH}-\mathrm{E}_{2}$ were used as substrates. For instance, the mutant $\mathrm{S}$ - and MB-COMTs have similar $\mathrm{K}_{\mathrm{M}}$ values (3.3 and $2.6 \mu \mathrm{M}$, respectively) as the wild-type $\mathrm{S}$ - and MB-COMTs (3.6 and $3.2 \mu \mathrm{M}$, respectively) for the $O$ methylation of $2-\mathrm{OH}-\mathrm{E}_{2}$. In addition, the mutant S-COMT had almost the same regio-preference for the 2-O-methylation of 2-OH- $\mathrm{E}_{2}$ over its 3-O-methylation as that of the wild-type S-COMT.

One of the notable differences between the mutant and wild-type human COMTs was the thermostability. While the wild-type human COMTs ( $\mathrm{S}$ - and MB-COMT) are very stable after $2 \mathrm{~h}$ of pre-incubation at $37^{\circ} \mathrm{C}$, the mutant COMTs lost $\sim 60 \%$ of their catalytic activity under the same preincubation conditions. Notably, earlier biochemical analyses of the V108M mutant and wild-type human S-COMTs also showed that whereas they had similar catalytic activity for the $O$-methylation of catechol estrogens in vitro, the mutant protein was more susceptible to heat inactivation $(35,36)$. In these cases, since the mutant enzymes are more unstable under prolonged incubation at $37^{\circ} \mathrm{C}$ (the physiological temperature), it is suggested that this will eventually result in decreased total levels of catalytically-active COMTs in a given tissue or cell.

In addition, we also noted a difference in the apparent $K_{M}$ values of the mutant and wild-type S-COMTs for the methyl donor AdoMet. Whereas the mutant S-COMT had a lower $\mathrm{K}_{\mathrm{M}}$ value than did the wild-type S-COMT when 2-OH- $\mathrm{E}_{2}$ was used as substrate, this difference disappeared when 4$\mathrm{OH}-\mathrm{E}_{2}$ was the substrate. As expected, the mutant and wildtype S-COMTs also had a different sensitivity to inhibition by AdoHcy, a demethylated AdoMet which binds to same pocket in the COMTs. The $I C_{50}$ value $(18.4 \mu \mathrm{M})$ of AdoHcy for the mutant $\mathrm{S}$-COMT was 3 -fold higher than the $I C_{50}$ value $(6.1 \mu \mathrm{M})$ for the wild-type S-COMT when $2-\mathrm{OH}-\mathrm{E}_{2}$ was the substrate, but when 4-OH- $\mathrm{E}_{2}$ was the substrate, the sensitivity of inhibition by AdoHcy was comparable (26.6 and $29.6 \mu \mathrm{M}$ ). Collectively, these data suggest that the mutant S-COMT has a higher binding affinity for AdoMet than does the wild-type $\mathrm{S}-\mathrm{COMT}$ when $2-\mathrm{OH}-\mathrm{E}_{2}$ is the substrate, and due to its higher binding affinity, the concentration of AdoHcy needed to compete for its binding site is proportionally higher.

To better understand the precise structural and functional differences between the D51G/S60F/K162R mutant of SCOMT and the wild-type protein, we have built the homology models of the mutant and wild-type S-COMTs for comparison. It is apparent that the overall secondary structure of the mutant enzyme and especially the structure of its catalytic site (built in two different ways) are very similar to those of the wild-type enzyme. Consistent with this observation, the calculated binding energy values $\left(\Delta E_{\text {binding }}\right)$ for the interactions of the mutant and wild-type enzymes with substrates were also comparable, which agreed well with the experimental data for the $O$-methylation of $2-\mathrm{OH}-\mathrm{E}_{2}$ and $4-\mathrm{OH}-\mathrm{E}_{2}$. The overall structural similarities between the mutant and wildtype S-COMTs likely are attributable to the following two factors: i) The three mutant amino acid residues were found to be located at the surface regions of the protein and were relatively distanced from the catalytic site. ii) Two of the three mutations were located in the loop regions of the protein sequence (S60F in loop 3 and K162R in loop 11), and their presence did not alter any of the existing $\alpha$-helical structures. Although D51 is located in the middle of $\alpha$-helix 3, this mutation also did not cause a disruption of the original $\alpha$ helical structure. 
In summary, we have identified a new human COMT haplotype with triple point mutations, i.e., D51G/S60F/K162R for S-COMT and D101G/S110F/K212R for MB-COMT. The selectively-expressed S- and MB-COMT proteins have been biochemically characterized for their catalytic and kinetic properties. Although the catalytic activity of the mutant Sand MB-COMTs does not differ significantly from that of the wild-type enzymes when $2-\mathrm{OH}-\mathrm{E}_{2}$ or $4-\mathrm{OH}-\mathrm{E}_{2}$ is the substrate, the mutant COMTs have a lower thermostability compared to the wild-type proteins. The mutant and wildtype S-COMTs have different binding affinities for AdoMet and AdoHcy, depending on the substrate used.

\section{Acknowledgements}

This study was supported, in part, by grants from the NIH (CA97109 and ES15242).

\section{References}

1. Axelrod J and Tomchick R: Enzymatic $O$-methylation of epinephrine and other catechols. J Biol Chem 233: 702-705, 1958.

2. Axelrod J: Methylation reactions in the formation and metabolism of catecholamines and other biogenic amines. Pharmacol Rev 18: 95-113, 1996.

3. Zhu BT: Catechol-O-methyltransferase (COMT)-mediated methylation metabolism of endogenous bioactive catechols and modulation by endobiotics and xenobiotics: importance in pathophysiology and pathogenesis. Curr Drug Metab 3: 321-49, 2002.

4. Tenhunen J, Salminen M, Jalanko A, Ukkonen S and Ulmanen I: Structure of the rat catechol- $O$-methyltransferase gene: separate promoters are used to produce mRNAs for soluble and membranebound forms of the enzyme. DNA Cell Biol 12: 253-263, 1993.

5. Zhu BT and Liehr JG: Quercetin increases the severity of estradiol-induced tumorigenesis in hamster kidney. Toxicol Appl Pharmacol 125: 149-158, 1994.

6. Zhu BT, Patel UK, Cai MX and Conney AH: $O$-methylation of tea polyphenols catalyzed by human placental cytosolic catechol-O-methyltransferase. Drug Metab Dispos 28: 1024-1030, 2000.

7. Zhu BT, Ezell EL and Liehr JG: Catechol-O-methyltransferasecatalyzed rapid $O$-methylation of mutagenic flavonoids. Metabolic inactivation as a possible reason for their lack of carcinogenicity in vivo. J Biol Chem 269: 292-299, 1994.

8. Zhu BT and Liehr JG: Inhibition of catechol $O$-methyltransferasecatalyzed $O$-methylation of 2 - and 4 -hydroxyestradiol by quercetin. Possible role in estradiol-induced tumorigenesis. J Biol Chem 271: 1357-1363, 1996.

9. Zhu BT: CNS dopamine oxidation and catechol-O-methyltransferase: importance in the etiology, pharmacotherapy, and dietary prevention of Parkinson's disease. Int J Mol Med 13: 343-353, 2004

10. Nackley AG, Shabalina SA, Tchivileva IE, Satterfield K, Korchynskyi O, Makarov SS, Maixner W and Diatchenko L: Human catechol- $O$-methyltransferase haplotypes modulate protein expression by altering mRNA secondary structure. Science 314: 1930-1933, 2006.

11. Diatchenoko L, Slade GD, Nackley AG, Bhalang K, Sigurdsson A, Belfer I Goldman D, Xu K, Shabalina SA, Shagin D, Max MB, Makarov SS and Maixner W: Genetic basis for individual variations in pain perception and the development of a chronic pain condition. Hum Mol Genet 14: 135-143, 2005.

12. Shield AJ, Thomae BA, Eckloff BW, Wieben ED and Weinshilboum RM: Human catechol $O$-methyltransferase genetic variation: gene resequencing and functional characterization of variant allozymes. Mol Psychiatry 9: 151-160, 2004.

13. Karayiorgou M, Altemus M, Galke BL, Goldman D, Murphy DL, Ott $\mathrm{J}$ and Gogos JA: Genotype determining low catechol- $O$ methyltransferase activity as a risk factor for obsessivecompulsive disorder. Proc Natl Acad Sci USA 94: 4572-4575, 1997.
14. Kirov G, Murphy KC, Arranz MJ, Jones I, McCandles F, Kunugi H, Murray RM, McGuffin P, Collier DA, Owen MJ and Craddock N: Low activity allele of catechol- $O$-methyltransferase gene associated with rapid cycling bipolar disorder. Mol Psychiatry 3: 342-345, 1998.

15. Papolos DF, Veit S, Faedda GL, Saito T and Lachman HM: Ultra-ultra rapid cycling bipolar disorder is associated with the low activity catecholamine- $O$-methyltransferase allele. Mol Psychiatry 3: 346-349, 1998.

16. Strous RD, Bark N, Parsia SS, Volavka J and Lachman HM: Analysis of a functional catechol- $O$-methyltransferase gene polymorphism in schizophrenia: evidence for association with aggressive and antisocial behavior. Psychiatry Res 69: 71-77, 1997.

17. Tiihonen J, Hallikainen T, Lachman H, Saito T, Volavka J, Kauhanen J, Syvälahti E, Hietala J and Tiihonen J: Association between the functional variant of the catechol-O-methyltransferase (COMT) gene and type 1 alcoholism. Mol Psychiatry 4: 286-289, 1999.

18. Enoch MA, Xu K, Ferro E, Harris CR and Goldman D: Genetic origins of anxiety in women: a role for a functional catechol- $O$ methyltransferase polymorphism. Psychiatr Genet 13: 33-41, 2003.

19. Rosa A, Peralta V, Cuesta MJ, Zarzuela A, Serrano F, MartinezLarrea A and Fañanás L: New evidence of association between COMT gene and prefrontal neurocognitive function in healthy individuals from sibling pairs discordant for psychosis. Am J Psychiatry 161: 1110-1112, 2004.

20. Nolan KA, Bilder RM, Lachman HM and Volavka J: Catechol $O$-methyltransferase Val158Met polymorphism in schizophrenia: differential effects of $\mathrm{Val}$ and Met alleles on cognitive stability and flexibility. Am J Psychiatry 161: 359-361, 2004.

21. Illi A, Mattila KM, Kampman O, Anttila S, Roivas M and Lehtimaki T: Catechol- $O$-methyltransferase and monoamine oxidase A genotypes and drug response to conventional neuroleptics in schizophrenia. J Clin Psychopharmacol 23: 429-434, 2003.

22. Zhu BT and Conney AH: Functional role of estrogen metabolism in target cells: review and perspectives. Carcinogenesis 19: 1-27, 1998.

23. Lee AJ, Cai MX, Tomas PE, Conney AH and Zhu BT Characterization of the oxidative metabolites of $17 \beta$-estradiol and estrone formed by 15 selectively expressed human cytochrome p450 isoforms. Endocrinology 144: 3382-3398, 2003.

24. Zhu BT and Conney AH: Is 2-methoxyestradiol an endogenous estrogen metabolite that inhibits mammary carcinogenesis? Cancer Res 58: 2269-2277, 1998.

25. Huang CS, Chern HD, Chang KJ, Cheng CW, Hsu SM and Shen CY: Breast cancer risk associated with genotype polymorphism of the estrogen-metabolizing genes CYP17, CYP1A1, and COMT: A multigenic study on cancer susceptibility. Cancer Res 59: 4870-4875, 1999.

26. Mitrunen K, Jourenkova N, Kataja V, Eskelinen M, Kosma VM, Benhamou S, Vainio H, Uusitupa $M$ and Hirvonen A: Glutathione S-transferase M1, M3, P1, and T1 genetic polymorphisms and susceptibility to breast cancer. Cancer Epidemiol Biomarkers Prev 10: 635-640, 2001.

27. Mitrunen K, Kataja V, Eskelinen M, Kosma VM, Kang D, Benhamou S, Vainio H, Uusitupa M and Hirvonen A: Combined COMT and GST genotypes and hormone replacement therapy associated breast cancer risk. Pharmacogenetics 12: 67-72, 2002.

28. Thompson PA, Shields PG, Freudenheim JL, Stone A, Vena JE, Marshall JR, Graham S, Laughlin R, Nemoto T, Kadlubar FF and Ambrosone CB: Genetic polymorphisms in catechol-Omethyltransferase, menopausal status, and breast cancer risk. Cancer Res 58: 2107-2110, 1998.

29. Suzuki K, Nakazato H, Matsui H, Koike H, Okugi H, Kashiwagi B, Nishii M, Ohtake N, Nakata S, Ito K and Yamanaka H: Genetic polymorphisms of estrogen receptor alpha, CYP19, catechol-O-methyltransferase are associated with familial prostate carcinoma risk in a Japanese population. Cancer 98: 1411-1416, 2003.

30. Yim DS, Parkb SK, Yoo KY, Yoon KS, Chung HH, Kang HL, Ahn SH, Noh DY, Choe KJ, Jang IJ, Shin SG, Strickland PT, Hirvonen A and Kang D: Relationship between the Val158Met polymorphism of catechol $O$-methyl transferase and breast cancer. Pharmacogenetics 11: 279-286, 2001. 
31. Goodman MT, McDuffie K, Kolonel LN, Terada K, Donlon TA, Wilkens LR, Guo C and Le Marchand L: Case-control study of ovarian cancer and polymorphisms in genes involved in catecholestrogen formation and metabolism. Cancer Epidemiol Biomarkers Prev 10: 209-216, 2001.

32. Lavigne JA, Helzlsouer KJ, Huang HY, Strickland PT, Bell DA, Selmin O, Watson MA, Hoffman S, Comstock GW and Yager JD: An association between the allele coding for a low activity variant of catechol- $O$-methyltransferase and the risk for breast cancer. Cancer Res 57: 5493-5497, 1997.

33. Lee SG, Joo Y, Kim B, Chung S, Kim HL, Lee I, Choi B, Kim C and Song K: Association of Ala72Ser polymorphism with COMT enzyme activity and the risk of schizophrenia in Koreans. Hum Genet 116: 319-328, 2005.

34. Lotta T, Vidgren J, Tilgman C, Ulmanen I, Melen K, Julkunen I and Taskinen J: Kinetics of human soluble and membranebound catechol $O$-methyltransferase: a revised mechanism and description of the therolabile variant of the enzyme. Biochemistry 34: 4202-4210, 1995

35. Li Y, Yao J, Chang M, Nikolic D, Yu L and Yager JD: Equine catechol estrogen 4-hydroxyequilenin is a more potent inhibitor of the variant form of catechol $O$-methyltransferase. Chem Res Toxicol 17: 512-520, 2004.
36. Goodman JE, Jensen LT, He P and Yager JD: Characterization of human soluble high and low activity catechol $O$-methyltrasferase catalyzed catechol estrogen methylation. Pharmacogenetics 12: 517-528, 2002.

37. Li Y, Yang X, Breemen RB and Bolton JL: Characterization of two new variants of human catechol $O$-methyltransferase in vitro. Cancer Lett 230: 81-89, 2005.

38. Zhu BT, Roy D and Liehr JG: The carcinogenic activity of ethinyl estrogens is determined by both their hormonal characteristics and their conversion to catechol metabolites. Endocrinology 132: 577-583, 1993.

39. Cohn CC, Dunner DL and Axelrod J: Reduced catechol-Omethyltransfease activity in red blood cells of women with primary affective disorder. Science 170: 125-135, 1970.

40. Tenhunen $\mathbf{J}$ and Ulmanen I: Production of rat soluble and membrane-bound catechol $O$-methyltransferase forms from bifunctional mRNAs. Biochem J 296(Pt 3): 595-600, 1993.

41. Winqvist R, Lundstrom K, Salminen M, Laatikainen M and Ulmanen I: The human catechol- $O$-methyltransferase (COMT) gene maps to band q11.2 of chromosome 22 and shows a frequent RFLP with BglI. Cytogenet Cell Genet 59: 253-257, 1992. 